\title{
INTELLIGENCE AS A PRODUCT MARKETING STRATEGY IN THE INTERNATIONAL MARKET
}

\section{Mohammad Noor Khairullah}

Departement of Management, STIE Widya Gama Lumajang, Lumajang, 67352, Indonesia

E-mail address: mohnoorkhairullah@gmail.com

\section{A R T I C L E I N F O}

Date of entry:

5 August 2020

Revision Date:

9 September 2020

Date Received:

14 September 2020

JEL Code: M31, J81, J54

\section{A B S T R A C T}

One principal use of language is to communicate meaning, but it is also to establish and maintain relationship. There are the different aims in speaking skill and the implementation in activity, for casual conversation and discussion. The aim of this study is to know the influence of Intelligence in using English with the marketing strategy of a product in the International Market. The design of this study is correlation design since it used statistical measurement for the data analysis to describe the relationship between two variables and is analyzed by using Pearson-Product Moment formula. There are 62 purposive sampling from 4 classes and using three instruments: test of IQ, documentation, and assessment. The result of this study is the influence of Intelligence in using English and the marketing strategy of a product in the International Market is dominant with coefficient correlation 0.220 . So, the null hypothesis (Ho) is rejected and the alternative hypothesis (Hi) is accepted.

Keywords: Intelligence, Speaking, Marketing and International Market

Cite this as: Khairullah, M. N. (2020). INTELLIGENCE AS A PRODUCT MARKETING STRATEGY IN THE INTERNATIONAL MARKET. International Journal of Accounting and Management Research, 1(2), 58-62. https://doi.org/10.30741/ijamr.v1i2.644

\section{INTRODUCTION}

Speaking is used for many different purposes, and each purpose involves different skill. Language is very important in life of people, because everyone need some help from the other people and he can get it if he just waits without trying find it, with the language and speaking he can get help by another people. It means that language as an instrument to make a conversation with the other people, and language will be understood if through the process of oral, that is speaking. Therefore, speaking can help people too easily and fast to understand about the language. Spolsky (1998: 3) says that one principal use of language is to communicate meaning, but it is also to establish and to maintain relationship. There are the different purposes in speaking skill and the implementation of speaking in activity: a) Speaking for casual conversation, have purposes may be to make social contact with people, to establish rapport. b) Speaking in discussion with someone, the purpose may be to seek or express opinions, to persuade someone about something or to clarify information (in Azhari: 2007).

English is important case in this research, because English is one of language which is used by all of the country in the world, and English as an instrument for the people to get much information from the native speaker. Considering the importance of language 
above, English as one of the languages used internationally facilities people get along with others over the world (in Ashari, 2005: 1). Bloomfield (in Sutikno: 1995) states that English is used widely all over the world; it is used for business, diplomacy, science, culture and education.

In daily activity, usually speaking is the way to make communication, to share about the ideas, to transfer the message and also to make interactional with the other people, and have the purpose to make the other people understand about language. Speaking is considered to be the most important skill (Ur, 1999:120). Ur (1999:120) states that learning speaking becomes the greatest interest for foreign language learners. Yet, the latest survey shows that the classroom situation in the teaching and learning of speaking is not conductive (Sinatra, 2009:3).

In speaking activity, the speakers need a feedback for the listener, so that the interaction of them will be happened and there is no misunderstanding between them. Speaking is social contact to make the condition and the situation is safe, because if everybody is difficult to speaking with each other, the condition will be uncomfortable. Absolutely, the relationship between them can be broken. According to Little (1982: 3) states that communication is the way in which we get in touch with each other how we saw each other our thoughts, ask questions; ask for help, pass on fact, argue, persuade others to do what we want them to do, explain, and give order. The common situation in speaking class is not alive, with the teacher's domination of the speaking activity. The teacher is not innovative in presenting the material, without trying to explore students' potentials in speaking. The students show low participation as they try to avoid the speaking turn by pointing to others to speak. Most students are shy and unwilling to speak. The speaking practice is limited to activities in the written form. In the classroom, teaching speaking is considering difficult for many English teachers. It seems that the students are reluctant or even afraid to speak up although their achievement in English components is satisfying. According to Johnson and Swain (1998), that phenomenon happens because the teaching of English is not meaningful. In addition, the students are given less opportunity to practice and use the language to communicate in real condition and situation.

Some people say that Intelligence and Intelligence Quotient (IQ) have the similarity in the meaning. Whereas, both of them have the basically different term in meaningful. According to David Wechsler (1944), Intelligence is the capability of people to act in a directed manner, rational thinking, and facing the environment effectively. Based on the explanation above, the conclusion about intelligence is the mental ability that involving the process of thinking rationally. Therefore, the intelligence could not be observed directly, rather should be concluded from several real actions which is manifestation form of that rational thinking process. While IQ or the abbreviation of Intelligence Quotient is the score which is gotten from the tool of intelligence's test. Thus, Intelligence Quotient (IQ) just giving a few of indication about the people of intelligence level and it does not describe someone's intelligence on the whole.

The core of Intelligence Quotient (IQ) is brain activation. Brain is the incredible part inside of us. It has weighed just $1.5 \mathrm{~kg}$ or approximately $5 \%$ from the total weigh of the human body. Nevertheless, it consumes more than $30 \%$ all of the reserve calories that is served inside of body. The brain of human has 10 to 15 billion nerve cells and every of it has thousands of connection. The human brain is the one part of body which continuing to grow as long it continuing to be activated. The capacity's memory of brain just used average $4-5 \%$ and for the genius one just used in $5-6 \%$.

Intelligence Quotient (IQ) begins to be fixed in average 3 years old. It is influenced by genetic of father's family and mother's family, and also another factor is enough food's nutrient. Intelligence Quotient (IQ) is assumed cannot be changed until growing up, except when happens the decrease of brain's function like as aging and accident. The high Intelligence Quotient (IQ) will make someone easy to learn and understand with some knowledge. The decrease of Intelligence Quotient (IQ) is the factor of problem in the 
learning process, besides there are the others factors, as physical interference, for example, high fever, weakness, sickness and emotional interference. The first time knowing the intelligence of a child is at while a child begins to talk. In this case, there is a connection directly between intelligence and language's ability.

Considering the explanation above, the researcher want to use speaking as the influence of Intelligence in using English by using correlation design to verify whether in the marketing strategy of a product in international market to improve students' English competency. The result of this research will be published scientifically in the journal of economic science research with the title, The Influence of Intelligence in Using English in The Marketing Strategy of a Product in The International Market.

\section{METHODS}

This research is quantitative research, because the data used the statistical analysis and also this research using correlation to described two or more variables. This research is using correlation design. On the other hand, the correlation design measures the correlation between two or more variables. The researcher is finding the influence of Intelligence in using English in the marketing strategy of a product in the International market. To find out the coefficient correlation, the researcher will use the formula of Pearson-product moment (Mistar, 2006: 21).

Population is big group which is as a subject in the research and also has the differences characteristic. According to Gay (1987: 102) states the population is the group of interest to the researcher, the group to which she or he would like the results of study to be generalizable. The definition of population has at least characteristic that differentiates it from other group. The target population of this research will be defined all of the students at the first semester in the English for Business lecturing of Management Department Widya Gama Lumajang in Academic Year 2020/2021. There are 428 students and they are divided into 12 classes.

Sample is small subject who taken by the researcher to be the representative of population for observation and analysis. In this research, the researcher determines the cluster sampling, in this research, the researcher will take 3 classes of 12 classes.

To collect data of Intelligence Quotient (IQ), the researcher uses a set documentation of Intelligence Quotient (IQ) test, it is consisted of 50 items in the form of multiple choices, and each item has 5 options. In this case, the researcher has given the final score of Intelligence Quotient (IQ) test. The data is gained from Speaking-Achievement Test. The researcher will use four components (Coherence, Pronunciation, Grammar, Vocabulary, and Fluency) are generally recognized in analysis of speaking test or speaking performance process.

Next step is the researcher asking a set of documentation from speaking test or speaking performance. Then computed the data to find out whether the students' Intelligence of using English is significant predictor in marketing strategy of a product in the International market or not.

\section{RESULTS AND DISCUSSION}

This analysis is intended to find out the relationship between score of Students' English Intelligence and Marketing Strategy of a Product in the International Market. The data to be analyzed were presented in the table. The computation of the figures, on the data of the correlation between score of Students' English Intelligence and Marketing Strategy of a Product in the International Market was carried out using Pearson-product moment. 
Tabel 1. Correlations

\begin{tabular}{llll}
\hline & & Intelligence & \multicolumn{1}{c}{ Marketing Strategy } \\
\hline \multirow{3}{*}{ Intelligence } & Pearson Correlation & 1 & $0,220^{*}$ \\
& Sig. (1-tailed) & & 0,043 \\
& $\mathrm{~N}$ & 62 & 62 \\
\hline \multirow{3}{*}{ Marketing Strategy } & Pearson Correlation & $0,220^{*}$ & 1 \\
& Sig. (1-tailed) & 0,043 & \\
& $\mathrm{~N}$ & 62 & 62 \\
$*$ *. Correlation is significant at the 0.05 level (1-tailed).
\end{tabular}

From the result of computing correlation above, it shows that the coefficient correlation between Students' English Intelligence and Marketing Strategy of a Product in the International Market is 0.220. According to the interpretation of the data, it can be concluded that the correlation between Students' English Intelligence and Marketing Strategy of a Product in the International Market is dominant significant. In the table of statistics, it was found that the critical value is 0.250 at the level of significance $\mathrm{p}<0.05$. The influence between Students' English Intelligence and Marketing Strategy of a Product in the International Market is significant, because the result is higher than the critical value at the table. So, the null hypothesis (Ho) is rejected and the alternative hypothesis (Hi) is accepted.

In this case, the data has been analyzed by Pearson-Product Moment correlation, the purposes is to find out whether there is significant correlation among two variables. According to the data, which was analyzed, show that the influence of Intelligence in using English correlates significantly in the marketing strategy of a product in the International market of Management Department Widya Gama Lumajang in Academic Year 2020/2021.

According to the data from the research finding which was calculated, (r) calculated is higher than the critical value $(r)$ at the table, and vice versa. The conclusion, the correlation investigated in the study is low and moderate.

\section{CONCLUSION}

Based on the objective of the study, which is to analyze whether there is significant correlation between the influence of Intelligence in using English and the marketing strategy of a product in the International market. The researcher has several conclusions as follows: The researcher hypothesizes (Hi) saying that, "There is dominant correlation between the influence of Intelligence in using English correlate with the marketing strategy of a product in the International market of Management Department Widya Gama Lumajang in Academic Year 2020/2021". This hypothesis is changed into a null hypothesis (Ho) saying, "The influence of Intelligence in using English at the marketing strategy of a product in the International market of Management Department STIE Widya Gama Lumajang in Academic Year 2020/2021 is not significant". The coefficient correlation between the influence of Intelligence in using English and the marketing strategy of a product in the International market is 0.220 and the critical value at the table is 0.250 . The conclusion, the null hypothesis (Ho) is accepted and the alternative hypothesis (Hi) is rejected.

Considering the result of this study, the researcher provides some suggestion for the teacher and the next researcher. Intelligence is an intellectual and knowledge ability for the human. In this case, the lecturer should know the students' problem and students' difficulties in English achievement and also give attention to the especially in English achievement. They must suppose and suggest them to use and practice it in every conversation. The parents should give more support to their children because it is useful for their study. The further researcher to add other variable which related to the students' speaking achievement and Intellectual Quotient IQ) such as motivation, attitude, spiritual quotient, etc. to give a new description for the reader. 


\section{REFERENCES}

Ashari, Ali. 2005. The predictability of students' speaking skill from their intelligence, emotional, interest at English Department of Faculty of Teacher Training and Education (FKIP) of Islamic University of Malang (UNISMA). Unpublished S-2 master thesis. Malang: UNISMA

https://study.com/academy/lesson/international-market-definition-lesson-quiz.html https://www.smartinsights.com/digital-marketing-strategy/customer-segmentationtargeting/segmentation-targeting-and-positioning/

Mistar, Junaidi. Handouts Statistics for Language Teaching Studies. Malang: UNISMA

Sinatra, Arni Ferra. 2010. Designing a Task-Based Activity for Teaching Speaking. In Bambang Yudi Cahyono (Eds). The Teaching of English Language Skills and English Language Components, 15(3). Malang: State University of Malang

Ur, P. 1999. A Course in Language Teaching: Practice and Theory. Cambridge: Cambridge University Press.

Wechsler, D.1944. The Measurement of Adult Intelligence. Baltimore: Williams \& Wilkins. $\underline{\text { ISBN }} \underline{0195022963}$. OCLC $\underline{5950992} \underline{219871557} \underline{5950992}$. ASIN = B000UG9J7E. 